\title{
Adıyaman ilinde Septoria Leke Hastalığının [Zymoseptoria tritici (Desm. Quaedvlieg \& Crous)] çıkış zamanı üzerinde iklim faktörlerinin etkisinin belirlenmesi
}

\section{Determination of theeffects of climate factors on the emergence time of Septoria Spot Disease [Zymoseptoria tritici (Desm. Quaedvlieg \& Crous)] in Adıyaman province of Turkey}

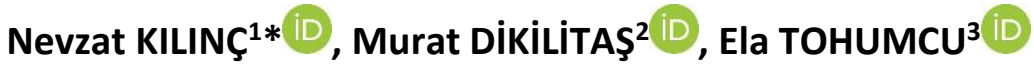 \\ ${ }^{1,2}$ Harran Üniversitesi, Ziraat Fakültesi, Bitki Koruma Bölümü, Ş.Urfa Türkiye \\ ${ }^{3}$ Sert Kabuklu Meyveler Araştırma Enstitüsü Müdürlüğü, Adıyaman Türkiye \\ ${ }^{1}$ https://orcid.org/0000-0002-5747-5467; ${ }^{2 h t t p s: / / o r c i d . o r g / 0000-0002-7399-4750 ; ~}{ }^{3 h t t p s: / / o r c i d . o r g / 0000-0001-6104-0346 ~}$
}

\section{To cite this article:}

Kılınç, N., Dikilitaş, M. \& Tohumcu, E. (2021). Adıyaman ilinde Septoria Leke Hastalığının [Zymoseptoria tritici (Desm. Quaedvlieg \& Crous)] çıkış zamanı üzerinde iklim faktörlerinin etkisinin belirlenmesi. Harran Tarım ve Gıda Bilimleri Dergisi, 25(3): 304-314.

DOI: $10.29050 /$ harranziraat. 895013

*Address for Correspondence: Nevzat KILINÇ

e-mail:

nvzt1298@gmail.com

Received Date:

11.03.2021

Accepted Date:

02.07.2021

(c) Copyright 2018 by Harran University Faculty of Agriculture. Available on-line at www.dergipark.gov.tr/harranziraat
Öz

Bu çalışma, 2019-2020 yılları arasında Adıyaman ili Samsat ilçesinde yürütülmüştür. Çalışmada, Septoria yaprak leke hastalığının (SYL) [Zymoseptoria tritici (Desm. Quaedvlieg \& Crous)] bölgede çıkış zamanı ve bu durum üzerine etkili olan iklim faktörleri incelenmiştir. İklim verilerini toplayabilmek amacıyla ilçede Taşkuyu Köyü, Göltarla Köyü, Ovacık Köyü ve Kuştepe Köyü'nde yer alan 4 adet tarımsal tahmin ve erken uyarı istasyonu kurularak elde edilen veriler değerlendirilmiştir. Gözlemler için istasyonlara yakın $(5-8 \mathrm{~km})$ Ceyhan-99 buğday çeşidi yetiştirilen 4 adet 100 dekarlık alan belirlenmiştir. Hastalıkı bitki örnekleri laboratuvarda patates dekstroz agar (PDA) ortamında kültüre alınarak patojenin gelişimi ve morfolojik yapısının Septoria yaprak leke hastalığı etmeni ile mikroskobik olarak uyumlu olduğu tanımlanmıştır. Tarımsal erken uyarı istasyonlarından alınan veriler ışı̆̆ında patojen üzerinde sıcaklık, nem, yağış ve yaprak ıslaklık süresinin etkili olduğu belirlenmiştir. illk hafif enfeksiyonların ortaya çıkışında yüksek nem ( $\geq \% 90)$ ve $1 \mathrm{~mm}$ üzerindeki yağış miktarı etkili olmuş, yağışın durmasını takiben $(R=0 \mathrm{~mm})$ sıcaklık artışı $\left(\geq 8^{\circ} \mathrm{C}\right)$ ile hastalık devam etmiştir. Hastalık belirtilerinin ortaya çıkışı üzerinde iklim faktörlerinin yanı sıra buğday çeşidi, ekim normu, ekim zamanı, ekim yapılan alanın konumu gibi faktörlerde yörede çıkış zamanı üzerinde etkili bulunmuştur. Bu çalışma ile ilk hastalık belirtilerinin 2020 yılı için ocak ayının ilk haftasında ortaya çıktığı belirlenmiştir. Patojene karşı uygulanacak mücadele zamanının belirlenmesinde çıkış zamanı ve iklim faktörleri bu çalışma ile ortaya konmuştur. Patojenlerin gelişimini önemli derecede sınırlandıran sıcaklık faktörü, nem olması durumunda ortamda bulunan patojenler için gelişme ortamı yaratmakta hatta onların adaptasyon kabiliyetini arttırmaktadır. Bu veriler ışığı altında adaptasyon kabiliyeti yüksek patojenlerin de tespiti mümkün olabilecektir.

Anahtar Kelimeler: Zymoseptoria tritici, İklim faktörleri, Buğday, Çıkış zamanı, Erken uyarı sistemi

\section{ABSTRACT}

This study was carried out between 2019-2020 in Samsat district of Adıyaman Province. In this study, the emergence time of Septoria leaf spot disease (SYL) [Zymoseptoria tritici (Desm. Quaedvlieg \& Crous)] in the region and the climatic factors affecting this situation were examined. In order to collect climate data, 4 agricultural forecasting and early warning stations were established in Taşkuyu, Göltarla, Ovacık and Kuştepe villages in the district and the data obtained were evaluated. In this research, 4 units of 100 decare areas close to the stations $(5-8 \mathrm{~km})$ were determined for observations. Ceyhan-99 wheat cultivar was grown in these areas. Diseased plant smples were cultured in the laboratory and according to the 
microscopic observations and morphological structures in the PDA medium, it was defined as Septoria leaf spot disease. In the light of the data obtained from the agricultural early warning stations, temperature, humidity, rain fall and leaf wetness periods were effective on the pathogen. High humidity (90\%) and rain fall over $1 \mathrm{~mm}$ were effective in the emergence of the first mild infections. The disease continued with an increase in the temperature $\left(\geq 8^{\circ} \mathrm{C}\right)$ following the cessation of rain $(R=0$ $\mathrm{mm}$ ). In addition to climatic factors, factors such as wheat variety, sowing norm, sowing time, and the location of the sown area were found to be effective on the emergence time in the region. With this study, it was determined that the first symptoms of the disease appeared in the first week of January, 2020. The emergence time and effective climate factors, which are important data in determining the time of control methods, have been reported in this study.

Key Words: Zymoseptoria tritici, Climate factors, Wheat, Exit time, Early warning system

\section{Giriş}

Dünyada 124 ülkede toplam 238.560.684 ha alanda üretimi yapılan buğday insan beslenmesinde oldukça önemli bir yere sahiptir (FAO, 2018). Buğday üretiminde abiotik ve biotik sebeplerden dolayı birçok ürün kayıpları gözlenmektedir. Özellikle Septoria yaprak lekesi hastalığı (SYL), buğdayda verim oranını \% 30- 50 oranında azaltmakta, bu nedenle, küresel gıda güvenliği için bir tehdit olarak görülmektedir (Sidhu ve ark., 2015). SYL'nin ülkemizde de oldukça yaygın olduğu ve bütün bölgelerde uygun iklim koşulları ve duyarlı çeşitler ile birleştiğinde önemli ürün kayıplarına sebep olabilecek potansiyele sahip olduğu bilinmektedir (İren, 1962; Bora ve Karaca, 1974; Akan ve ark., 2006; İlgen ve ark., 2017; Özdemir ve ark., 2017). Hastalık etmeni ile mücadelede birçok koruyucu fungisit önerilmesine karşın, ilaçlama dozu ve ilaçlama zamanlarının tam olarak üretici tarafından belirlenememesinden dolayı özellikle kışlık buğday çeşitlerinde kimyasal mücadeleye rağmen \%40'lara varan ürün kayıpları meydana gelmektedir. Dayanıklı çeşitlerin tercih edilmesi hastalık ile mücadelede önemli rol oynamaktadır (Torriani ve ark., 2009).

SYL hastalığı, ilk olarak bitkide yaprak üzerinde küçük, düzensiz, kırmızımtırak-kahverengi lekeler şeklinde görülür, ilerleyen dönemlerde bu lekeler genişleyerek yaprağın kurumasına neden olur. Hastalık etmenin gelişimi için optimum sıcaklık 20$25^{\circ} \mathrm{C}$ olmasına rağmen, etmen $5-35^{\circ} \mathrm{C}$ arasındaki sıcaklıklarda canlılık faaliyetlerini sürdürür. $\mathrm{Bu}$ nedenle buğday bitkisi kardeşlenme döneminden bayrak yaprak dönemine kadar olan dönemde hastalık etmeninin tehdidi altında kalmaktadır. Etmenin ana konukçusu buğday olmakla beraber arpa ve çayır bitkilerinde de hastalık etmenine rastlanılmaktadır. Anız, kendigelen buğday ve buğdaygil tohumu ve yabancı otlar SYL'nin inokulum kaynaklarını oluşturmaktadır (Kurt, 2016).

Entegre mücadelede hastalık yönetimi ve hastalık tahmin modelleri, tarımda sürdürülebilir uygulamalara olan ihtiyaç nedeniyle giderek önem kazanmıştır (Langvad ve Noe, 2006). Fungisit kullanım zamanlarını optimize etmek ve tarımsal faaliyetlerde patojen-bitki hastalıkları hakkında güvenilir bilgi elde etmek için erken uyarı ve tahmin önemli bir yer tutmaya başlamıştır (Fones ve Gurr, 2015).

Uygun meteorolojik koşullar, bitkilerde fungal hastalıkların salgınlar oluşturmasını ve patojenkonukçu etkileşimini belirleyen temel unsurlardandır. Meteorolojik koşullar arasında hava sıcaklığı $(T)$, bağıl nem $(R H)$, yağış $(R)$ ve yaprak ıslaklık süresi (LWT), patojen-konukçu etkileşiminde önemli bir yere sahiptir. İklim faktörlerinden T, RH ve R'nin SYL'inin enfeksiyonu ve ilerlemesi üzerindeki etkileri birçok çalışmada vurgulanmıştır (Lovell ve ark., 2004 ). SYL'nin gelişimde $T$, fungus gelişimi ve spor dağılımı işlemlerinin meydana gelme oranını belirler (Gladders ve ark., 2001). Sıcaklık değeri $-2^{\circ} \mathrm{C}$ 'nin altında geçen uzun bir $T$ periyodu, fungus üzerinde olumsuz etkilere neden olmaktadır. Bu durum patojen miktarının azalmasına neden olarak buğday bitkisini enfekte etmek için inokulumu azaltmaktadır ( Shaw ve Royle, 1993 ).

$\mathrm{Bu}$ durum ileriki dönemlerde hava koşulları uygun olsa bile, baharda salgının geç veya çok yavaş gelişmesine yol açar (Parker ve ark., 2004). SYL sporları içine su alarak çimlenir ve enfeksiyon gerçekleşir, eğer ortamda yeterli RH yoksa salgın yavaşlar. Çünkü nem tek başına salgının gelişme 
hızını etkileyebilir. Abiyotik stres koşullarında $\mathrm{RH}^{\prime} \mathrm{a}$ uyum sağlayarak, adapte olan patojenlerin yüksek sıcaklıklarda adaptasyonu için RH oranı önemlidir. Özellikle $\% 60$ ve daha üzeri oranlardaki nem salgının gelişme hızı üzerinde etkilidir (Thomas ve ark., 2018). Patojen üzerinde etkili olan bir diğer faktör ise yağıştır. Piknidyumların şişmesine neden olduğu ve sporların buğday bitkisinin üst yapraklarına sıçramasına yardımcı olduğu için SYL'nin gelişimi için önemli bir kriterdir (Gladders ve ark., 2001 ).

Bölgesel ölçekte hastalık riski tahmin değerlendirmeleri otomotik hava istasyonları (AWS) ve iMETOS IOT İstasyonundan sağlanan veri ağları esas alınarak yapılmaktadır (Te Beest ve ark., 2009).

Değişen iklim değerleri özellikle küresel ısınmanın giderek artması tarım ürünleri üzerinde önemli bir stres faktörü olmaya başlamıştır. Yeni koşullara karşı daha dayanıklı bitkilerin geliştirilmesi kaçınılmaz olmakta, benzer şekilde bitki patojenleri de değişen iklim koşullarından etkilenmekte ve bir şekilde adaptasyon sağlayıp bitkileri hastalandırmaya devam etmektedirler. Değişen iklim değerleri patojenlerin hastalık yapma zamanlarını da etkilemektedir. Dünyada ve ülkemizde önemli bir besin kaynağı olan buğday bitkisinde hastalığa neden olan söz konusu patojenin hastalık yapma zamanı ve bunu etkileyen iklim faktörlerinin belirlenmesi, gelecekte bu hastalıkla mücadelede kullanılacak yöntemlerin belirlenmesinde önemli bir katkı sağlayacaktır.

Abiyotik stres koşulları bitki üzerinde stres oluşturduğu gibi patojenlerde de stres oluşturmaktadır. Ortamda nem olması durumunda patojenlerin sıcaklığı tolere edebildiği görülmüş, bu durum sıcaklığa adaptasyonda önemli bir adım olarak görülmüştür (Dikilitaş ve ark., 2018).

\section{Materyal ve Metot}

Bu araştırma, 2019-2020 yılları arasında Adıyaman îli Samsat ilçesinde yürütülmüştür. Araştırmada, Ceyhan-99 buğday çeşidi, Septoria yaprak leke hastalığı [Zymoseptoriatritici (Desm. Quaedvlieg \& Crous)] patojeni, tarımsal tahmin ve erken uyarı istasyonları, çeşitli laboratuvar malzemeleri ve hazır kültür ortamları çalışmanın ana materyallerini oluşturmuştur.

Tarımsal tahmin ve erken uyarı istasyonlarının kurulumu

Meteorolojik verilerin elde edilmesi için bütün ilçede buğday üretim alanlarını kapsama alanı içine alacak şekilde 4 adet tarımsal tahmin ve erken uyarı istasyonu (Taşkuyu Köyü, Göltarla Köyü, Ovacık Köyü, Kuştepe Köyü) kurulmuştur.ìstasyonların sahip olduğu özellikler, hesaplanan sensör değişkenleri iMETOS IMT300 sensör setine eşittir; bunlar rüzgar hızı, güneş radyasyonu, toprak sıcaklığı, hava sıcaklığı, yağış, bağıl nem ve yaprak ıslaklığı ile birlikte hesaplanan ETO, buhar basıncı açığı (VPD) ve Delta T değerleridir (Henze, M., 2008). Bütün verilere ve karar destek hizmetlerine telefon ve bilgisayarlara önceden kurulmuş olan FieldClimate platformu üzerinden çevrimiçi olarak erişim sağlanmıştır. Programa firma (METOS TR Bilişim Tarım Teknolojileri San. ve Tic. Ltd. Şti., Mersin) tarafından temin edilen, araştırıcıların denemeleri sonucu tanımlanmış olan SYL hastalığının ortaya çıktığı hava koşullarını içeren hastalık modelleme programı da eklenerek, tarla kontrolleri ile istasyon tahmin verileri arasındaki uyumluluk gözlemlenmiştir.

\section{Buğday ekim alanlarının belirlenmesi}

Ekim alanları belirlenirken daha önceki yıllarda SYL hastalığının yoğun olarak görüldüğü alanlara göre yer seçimi yapılmıştır. Buna göre 4 adet 100 dekarlık alan belirlenip buğday tohumu ekimleri tamamlanmıştır. Sonraki günlerde ekim tarihinden itibaren 10 günde bir tarla kontrolleri yapılarak elde edilen gözlemler kayıt altına alınmıştır. Belirlenen alanlara Çizelge 1'de görülen tarımsal mekanizasyon, gübreleme, yabancı ot ilaçlaması ve ekim normu gibi işlemler aynı tarihlerde yapılarak bu faktörlerin hastalık gelişimi üzerindeki etkileri en aza indirilmiştir. Denemelerde kullanılan Ceyhan-99, bölgede 
yaygın olarak kullanılmakta olan bir çeşit olup, sarı pas ve SYL etmenine dayanıklı, kahverengi pasa ise orta derecede dayanıklı olarak rapor edilmiştir (Çukurova Tarımsal Arş. Ens., 2019).

Çizelge 1. Araştırmanın yürütüldüğü alanlarda yapılan uygulamalar

Table 1. Applications in the areas where the research was carried out

\begin{tabular}{|c|c|c|c|c|c|c|}
\hline $\begin{array}{l}\text { Yer } \\
\text { Location } \\
\text { (Adıyaman/Samsat) }\end{array}$ & $\begin{array}{l}\text { GPRS } \\
\text { Konum } \\
(x y) \\
\text { Location }\end{array}$ & $\begin{array}{l}\text { Alan } \\
\text { (dekar) } \\
\text { Area } \\
\text { (decares) }\end{array}$ & $\begin{array}{l}\text { Çeşit } \\
\text { Wheat } \\
\text { cultivar }\end{array}$ & $\begin{array}{l}\text { Ekim tarihi } \\
\text { Planting } \\
\text { date }\end{array}$ & $\begin{array}{l}\text { Gübreleme } \\
\text { Fertilization }\end{array}$ & $\begin{array}{l}\text { Yabancl ot } \\
\text { mücadelesi } \\
\text { Weed control }\end{array}$ \\
\hline & & & & & Ekim $\quad 6-8 \mathrm{~kg} \quad \mathrm{da}^{-1}$ & \\
\hline Taşkuyu Köyü & $\begin{array}{l}37.6119- \\
38.4895\end{array}$ & 100 & Ceyhan 99 & 26.11.2019 & $\begin{array}{l}\text { Fosfor,7-8 kg da-1 Azot, } \\
\text { Kardeşlenme } 7-8 \mathrm{~kg} \mathrm{da} \\
{ }^{1} \text { Saf Azot }\end{array}$ & 19.03.2020 \\
\hline Göltarla Köyü & $\begin{array}{l}37.6060- \\
38.4436\end{array}$ & 100 & Ceyhan99 & 27.11.2019 & $\begin{array}{l}\text { Ekim 6-8kgda }{ }^{-1} \text { Fosfor,7- } \\
8 \text { 8kgda }{ }^{-1} \text { Azot, } \\
\text { Kardeşlenme } 7-8 \text { kgda- } \\
{ }^{1} \text { saf Azot }\end{array}$ & 20.03.2020 \\
\hline Ovacık Köyü & $\begin{array}{l}37.5597- \\
38.4289\end{array}$ & 100 & Ceyhan99 & 28.11.2019 & $\begin{array}{l}\text { Ekim 6-8kgda-11 Fosfor,7- } \\
8 \mathrm{kgda}^{-1} \text { Azot, } \\
\text { Kardeşlenme } 7-8 \mathrm{~kg} \mathrm{da}- \\
{ }^{1} \text { saf Azot }\end{array}$ & 21.03.2020 \\
\hline Kuştepe Köyü & $\begin{array}{l}37.5445- \\
38.3988\end{array}$ & 100 & Ceyhan99 & 26.11.2019 & $\begin{array}{l}\text { Ekim 6-8kgda-11 Fosfor,7- } \\
8 \mathrm{kgda}^{-1} \text { Azot, } \\
\text { Kardeşlenme } 7-8 \mathrm{kgda}^{-} \\
{ }^{1} \text { saf Azot }\end{array}$ & 21.03.2020 \\
\hline
\end{tabular}

Septoria yaprak leke hastalığının örnekleme yöntemi

SYL etmenini elde etmek için ekimi yapılmış buğday tarlaları ile bu arazilerin etrafındaki yabancı otlardan hastalık örnekleri toplanmıştır. Enfekteli yaprak örneklerinden patojen izole edildikten sonra labaratuvar ortamında kültüre alınmıştır. Hastalığın çıkış dönemlerini belirlemek için buğday bitkisinin çimlenme, kardeşlenme ve süt olum dönemlerinde gözlemler yapılmıştır. Hasatlığın neden olduğu belirtilerin değerlendirilmesinde, hastalık şiddeti ıskalasından (Çizelge 2.) faydalanılmıştır (Aktaş, 2001).

Çizelge 2. Septoria leke hastalığının hastalık şiddeti değerlendirme ıskalası

Table3. Disease severity assessment scale for Septoria spot disease

\begin{tabular}{lll}
\hline $\begin{array}{l}\text { Iskala Değeri } \\
\text { Scale Value }\end{array}$ & $\begin{array}{l}\text { Hastalık Şiddeti } \\
\text { Disease Severity }\end{array}$ & $\begin{array}{l}\text { Enfeksiyon Tipi } \\
\text { Infection Type }\end{array}$ \\
\hline 0 & Hiç simptom yok (0) & Sağlam \\
\hline 1 & Çapı 0.5 mm'den küçük sarı lekeler var(\%10'dan az lekeli alan) & Çok dayanıklı \\
\hline 2 & $\begin{array}{l}\text { Genişliği } 1 \mathrm{~mm} \text { ve boyu } 0.5-1 \quad \mathrm{~cm} \text { 'den küçük oval nekrotik lekeler, piknidya } \\
\text { gelişmesi yok veya birkaç adet(\%11-25 lekeli alan) }\end{array}$ & Dayanıklı \\
\hline 3 & $\begin{array}{l}\text { Genişliği 1-2mm uzunluğu } 1-1.5 \mathrm{~cm} \mathrm{oval} \mathrm{lekeler} \mathrm{bazıları} \mathrm{birleşik} \mathrm{halde,} \mathrm{hafif} \\
\text { piknidya gelişmesi var(\%26-45 lekeli alan) }\end{array}$ & Orta duyarlı \\
\hline 4 & $\begin{array}{l}\text { Lekelerin çoğu birleşmiş halde nekrotik leke yok, çok sayıda piknidya gelişmesi } \\
\text { var(\%46-75 lekeli alan) }\end{array}$ & Duyarlı \\
\hline 5 & Lekeler tamamen birleşmiş, çok sayıda piknidya gelişmesi var(\%76-100 lekeli alan) & Çok duyarlı
\end{tabular}

\section{Patojenin izolasyonu ve kültüre alınması}

Hastalıklı bitki örneklerinden elde edilen piknitli yaprak parçaları şeffaf bant yardımı ile lam üzerine tutturulmuştur. Hazırlanan örnekler steril su ile nemlendirilmiş kurutma kâğıdı içeren Petri kutularına yerleştirilmiştir. Piknidiospor çıkışının sağlanabilmesi için piknitli yapraklar nemli ortamda $18-20^{\circ} \mathrm{C}^{\prime}$ de $15-20$ saat bekletilmiştir.
Piknitler üzerinden akan sızıntı gözlemlenmiş ve bu sızıntılardan steril iğne yardımıyla alınan parçalar, Çizelge 3 'de verilen antibiyotikli PDA ortamına aktarılmıştır. Örneklerin alındığı Petri kutuları $18-20^{\circ} \mathrm{C}^{\prime}$ de 3 gün boyunca 12 saat aydınlık 12 saat karanlıkta inkübasyona tabi tutulmuştur (Eyalve ark., 1987). Gelişmeye bırakılan fungus kolonilerinden, $10 \mathrm{~mm}$ çapında bir 
fungal disk, ortamdan bir mantar delici yardımı ile kesilerek, yeni hazırlanan PDA ortamlarına aseptik koşullarda aktarılmıştır. Birkaç gün bulaşma olup olmadığı gözlemlendikten sonra inkubasyona bırakılmıştır. $\mathrm{Bu}$ şekilde deneme süresince kullanılan fungus kültürleri elde edilmiştir.

Çizelge 3.Denemede kullanılan antibiyotikli Patates Dekstroz Agar (PDA)

Table3. Potato Dextrose Agar with antibiotics used in the experiment (PDA)

\begin{tabular}{ll}
\hline İçerik & Konsantrasyon $\left(\mathrm{gL}^{-1}\right)$ \\
Content & Concentration \\
\hline Kabuğu soyulmuş, doğranmış patates & 200 \\
Glukoz & 15 \\
OxoidAgar No:3 & 25 \\
Streptomycin & 0.03 \\
\hline
\end{tabular}

Buna göre $200 \mathrm{~g}$ soyulmuş patates küçük parçalara dilimlenmiş ve 1000 ml'lik saf su içinde 30 dakika kaynatılmıştır. Elde edilen püre, mira bezinden (Calbiochem) süzüldükten sonra geriye kalan çözeltiye15 g glukoz eklenmiştir. Bu ortam $250 \mathrm{ml}$ hacime $6.25 \mathrm{~g}$ agar içerecek şekilde (\%2.5 $\left.w^{-1}\right) \quad 8$ adet 500 ml'lik konikal flasklara aktarılmıştır. Ortam $121^{\circ} \mathrm{C}$ 'de 20 dakika (2.68 $\mathrm{kgcm}^{2}$ basınçta) otoklavlanmış ve Petri kutularına aktarılmıştır (Dikilitaş ve ark., 2018).Otoklav işleminden sonra $50 \mathrm{mM}$ çapında filtreden geçirilen streptomycin $\left(30 \mathrm{mg} \mathrm{L}^{-1}\right)$ ortama ilave edilmiştir.

\section{Araştırma Bulguları ve Tartışma}

SYL etmeninin izole edilmesi ve kültüre alınması

Hastalık etmenin gözlemlendiği alanlardan alınan örnekler laboratuvar koşullarında kültüre alındıktan 12 gün sonra fungus izolatlarında spor sayımı yapılmıştır. Bunun için, fungus kolonilerinden birer adet fungal disk $(5 \mathrm{~mm}$ çapında) alınarak (3 tekkerür) tüplere konmuş ve $1 \mathrm{ml}$ su içinde sporlar ayrıştırıldıktan sonra tüpler vibratörde çalkalanarak sporların homojen bir şekilde suda dağılması sağlanmıştır. Elde edilen spor süspansiyonundan $10 \mu l^{\prime}$ lik bir hacim alınarak heamocytometre üzerinde ışık mikroskobu (SOIF B203, 10x40 büyütme) altında fungal spor sayımı yapılmıştır $\left(13.8 \times 10^{6}\right.$ spor $\left.\mathrm{ml}^{-1} \mathrm{~mm}^{-2}\right)$. Yapılan mikroskobik incelemeler sonucunda etmenin SYL olduğu tespit edilmiştir (Şekil 1).

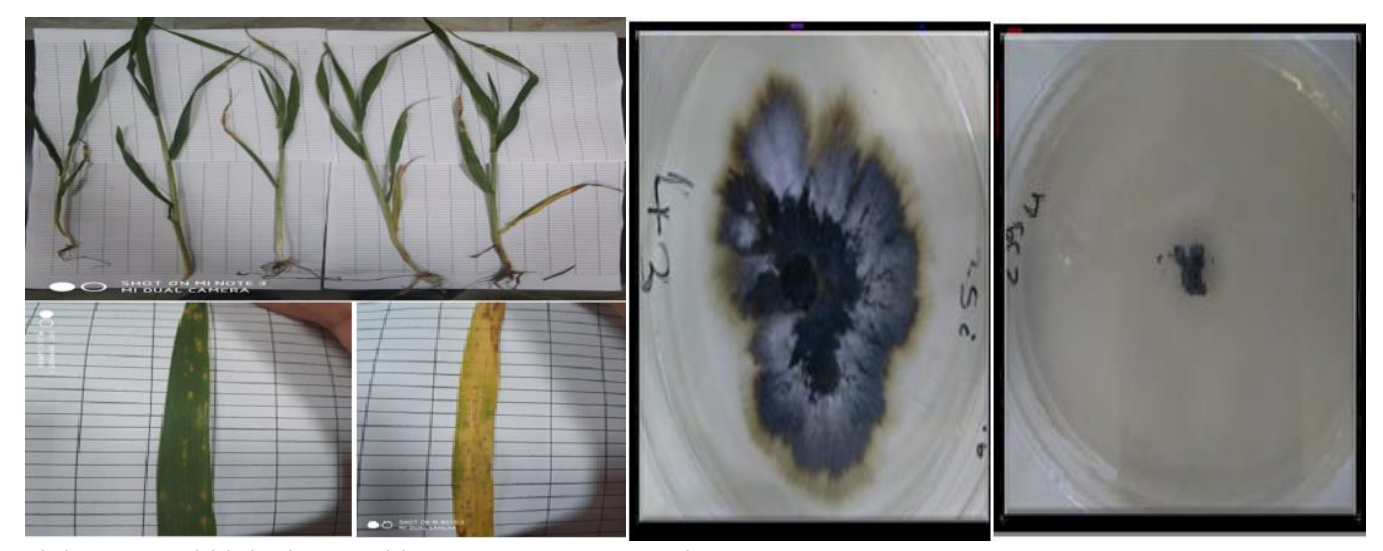

Şekil 1. Hastalıklı bitki örnekleri ve PDA ortamında SYL etmeninin görünüşü

Figure 1. Diseased plant samples and macroscopic appearances of SYL agent in PDA.

Tarımsal tahmin ve erken uyarı istasyonlarının kurulumu

Çalışma kapsamında 2019 yılı eylül ayı içerisinde 4 adet tarımsal tahmin ve erken uyarı istasyonu Adıyaman illi Samsat İlçesinin Göltarla, Kuştepe, Ovacık ve Taşkuyu köylerinde kurulmuştur (Şekil 2). 


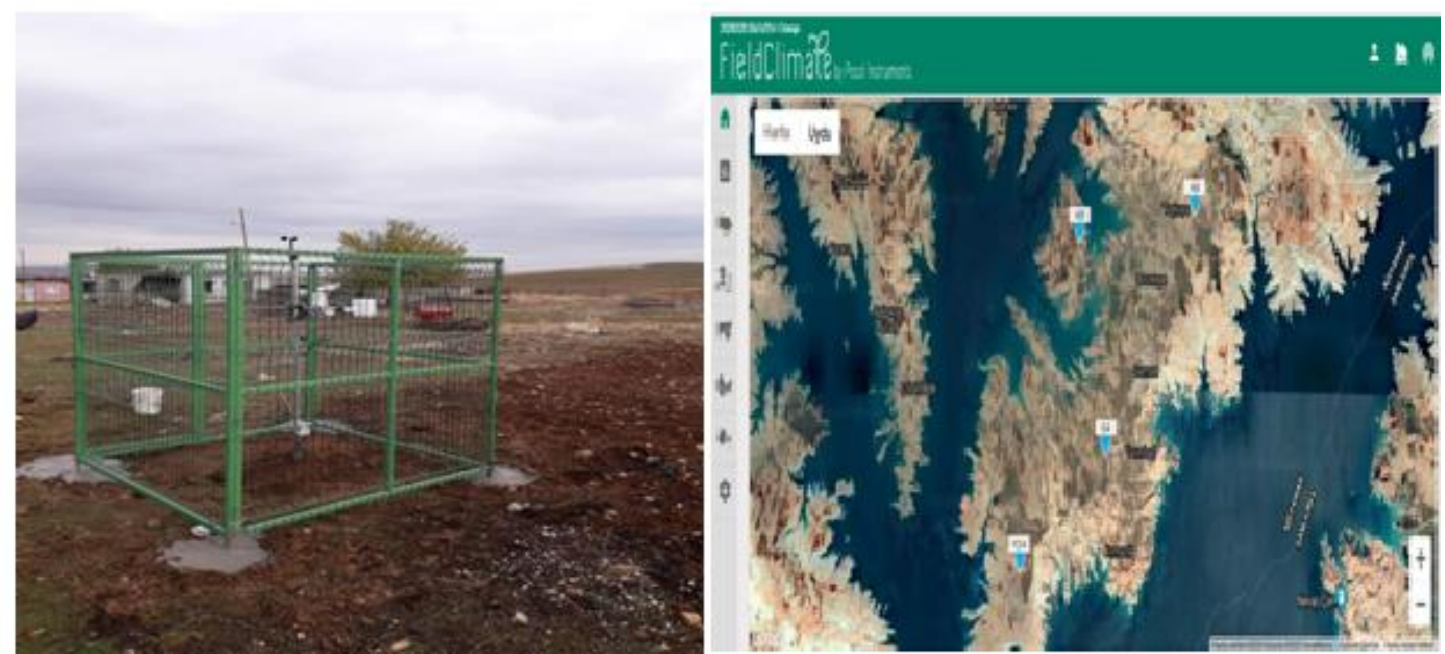

Şekil 2. Tarımsal tahmin ve erken uyarı istasyonlarından genel görünüm ve uydu konumları Figure 2. Satellite locations of agricultural forecast and early warning stations

Kuştepe Köyü SYL hastalık çıkışı ve hastalık şiddetinin değerlendirilmesi

Yapılan tarla kontrolleri ve istasyonlardan alınan veriler sonucunda sıcaklık $(\mathrm{T}): 6.13^{\circ} \mathrm{C}$, nisbi nem $(\mathrm{RH}): \% 91.95$, yağış $(\mathrm{R}): 1.6 \mathrm{~mm}$ ve yaprak ıslaklık süresinin (LWT) 60 dakika olduğu meteorolojik şartlarda hastalık etmeninin ilk belirtilerinin ortaya çıktığı belirlenmiştir. SYL hastalık modelleme programında, istasyonlardan elde edilen iklim paramatreleri, Hafif enfeksiyon, orta enfeksiyon ve ağır enfeksiyon riskleri şeklinde yüzdelik oran olarak guruplandıran yazılım programı içermektedir.
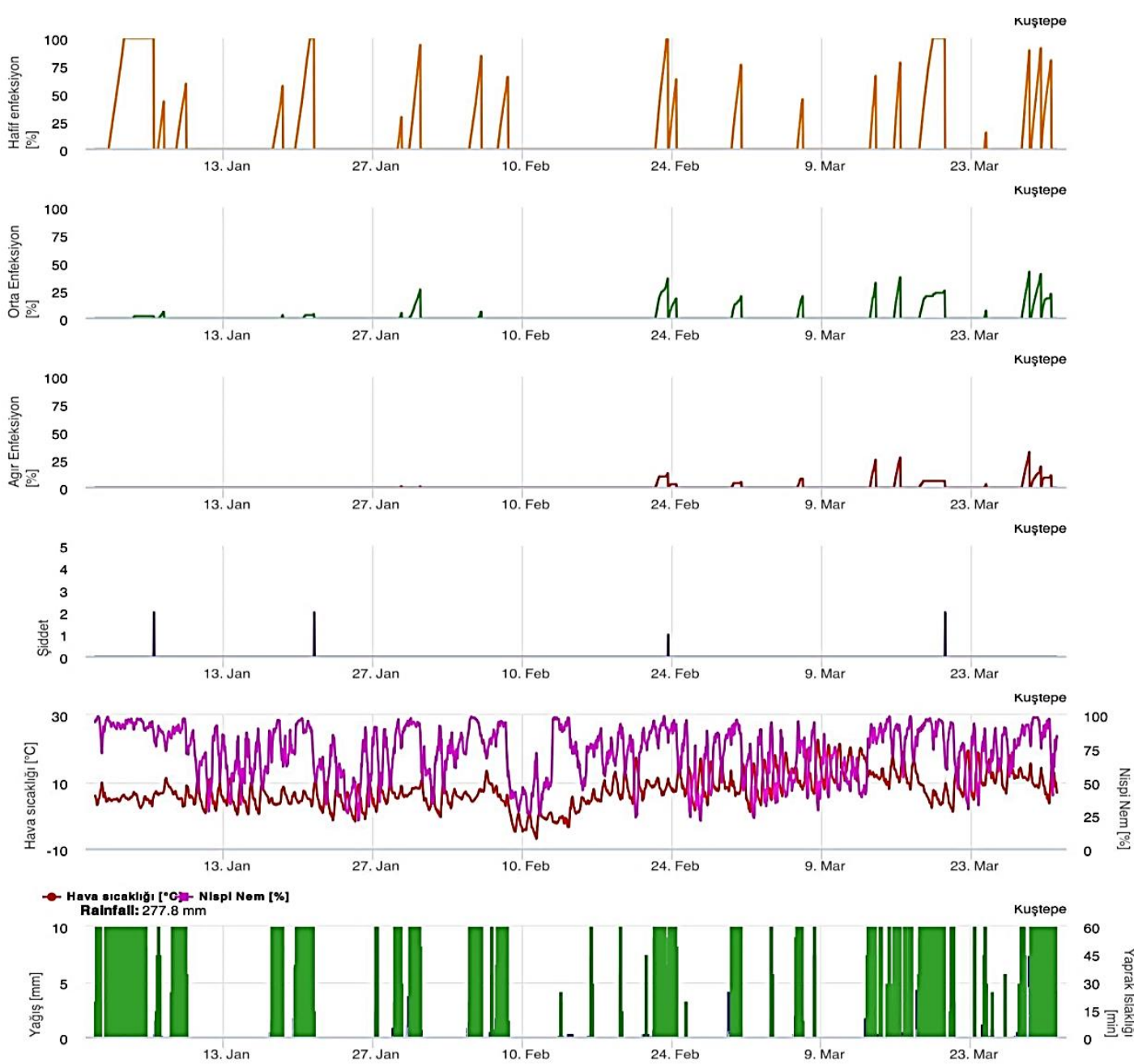

Şekil 3. Kuştepe Köyü tahmin ve erken uyarı istasyonu verileri

Figure 3. Kuştepe village station forecast and early warning data 
Buna göre hafif enfeksiyon oranı \%3, (FieldClimate platformu üzerinden hastalık modelleme programına göre ) hastalık şiddetinin ise sıfır olduğu belirlenmiştir. Hastalık şiddetinin 2 olarak görüldüğü (SYL hastalık değerlendirme ıskalası) hava koşulları ise $\mathrm{T}: 6.3^{\circ} \mathrm{C}, \mathrm{RH}: \% 93.13 \mathrm{R}: 0$ $\mathrm{mm}$ ve LWT: 60 dakika olarak belirlenmiştir. Hastalık şiddeti 2 olduğunda SYL moddeleme programında hafif enfeksiyon oranı $\% 100$ belirlenmiştir (Şekil 3).
Göltarla Köyü SYL hastalık çıkışı ve hastalık şiddetinin değerlendirilmesi

Göltarla Köyü'nde bulunan tarımsal tahmin ve erken uyarı istasyonundan alınan veriler ve tarla kontrolleri sonucunda ilk hafif enfeksiyon oranı $\% 6$ değerini veren iklim parametreleri, $\mathrm{T}: 5.14^{\circ} \mathrm{C}$; RH: \%93.56; R:1.6 mm ve LWT: 60 dakika olarak ölçülmüştür. Hastalık şiddetinin 2 olarak değerlendiği hafif enfeksiyon oranının \%100 olduğu hava koşulları ise $\mathrm{T}: 5.68^{\circ} \mathrm{C} ; \mathrm{RH}: \% 83.81 ; \mathrm{R}$ : $0 \mathrm{~mm}$ ve LWT: 55 dakika olarak bulunmuştur (Şekil 4).
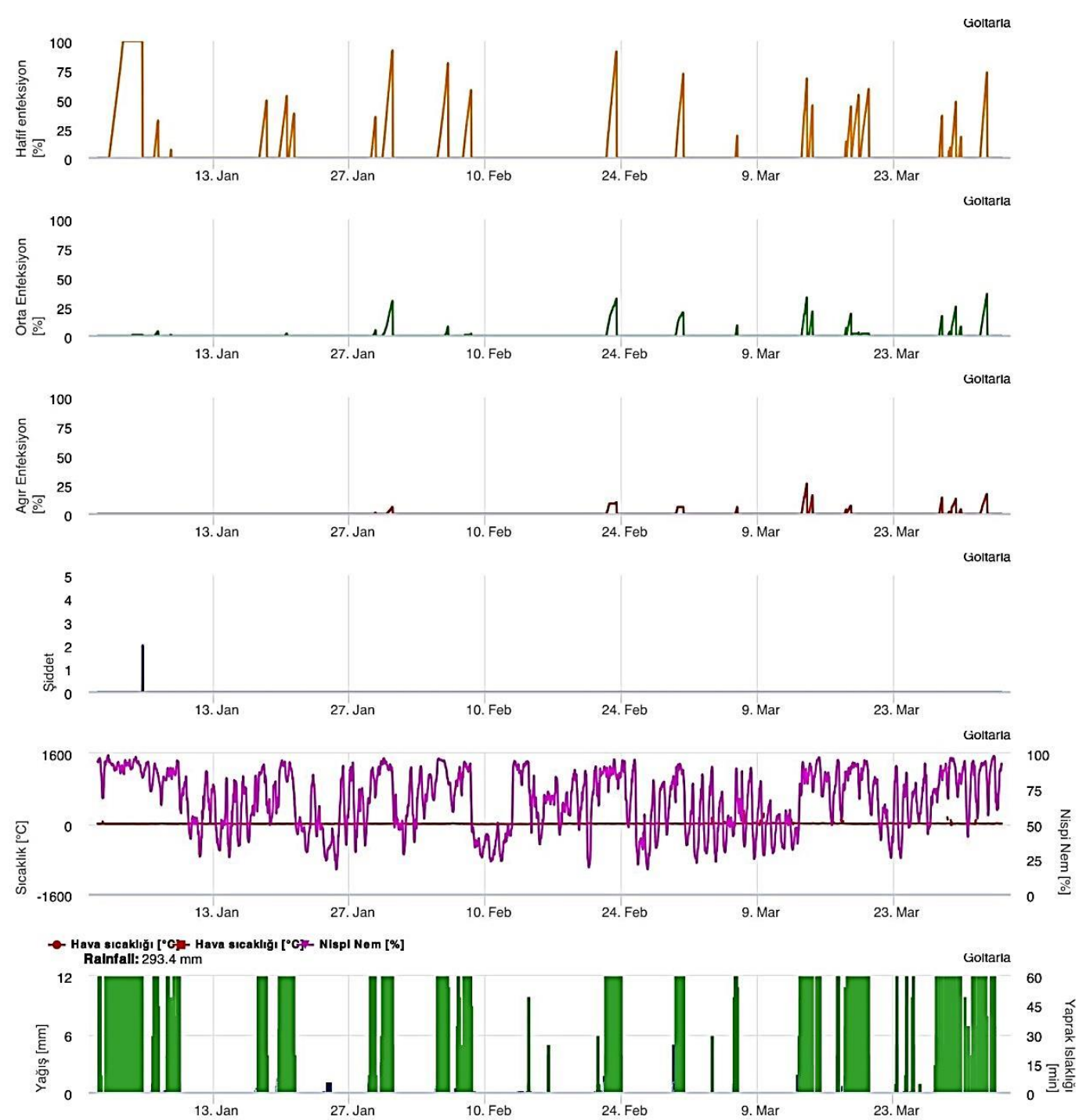

Şekil 4. Göltarla Köyü tahmin ve erken uyarı istasyonu verileri

Figure 4. Göltarla Village station forecast and early warning data

Ovacık Köyü SYL hastalık çıkışı ve hastalık şiddetinin değerlendirilmesi

Ovacık Köyü'nde bulunan tarımsal tahmin ve erken uyarı istasyonundan alınan veriler ve tarla kontrolleri sonucunda ilk hafif enfeksiyon oranı \%8 değerini veren iklim parametreleri ise $\mathrm{T}$ :
5.05 ${ }^{\circ} \mathrm{C}$; RH: \%93.79; R: $6.6 \mathrm{~mm}$ ve LWT: 60 dakika olarak ölçülmüştür. Hastalık şiddetinin 2 olarak değerlendiği hafif enfeksiyon oranının \%100 olduğu hava koşulları ise $\mathrm{T}: 7.06^{\circ} \mathrm{C}$; $\mathrm{RH}$ : \%80.00; R: $0 \mathrm{~mm}$ ve LWT: 20 dakika olarak bulunmuştur (Şekil 5). 

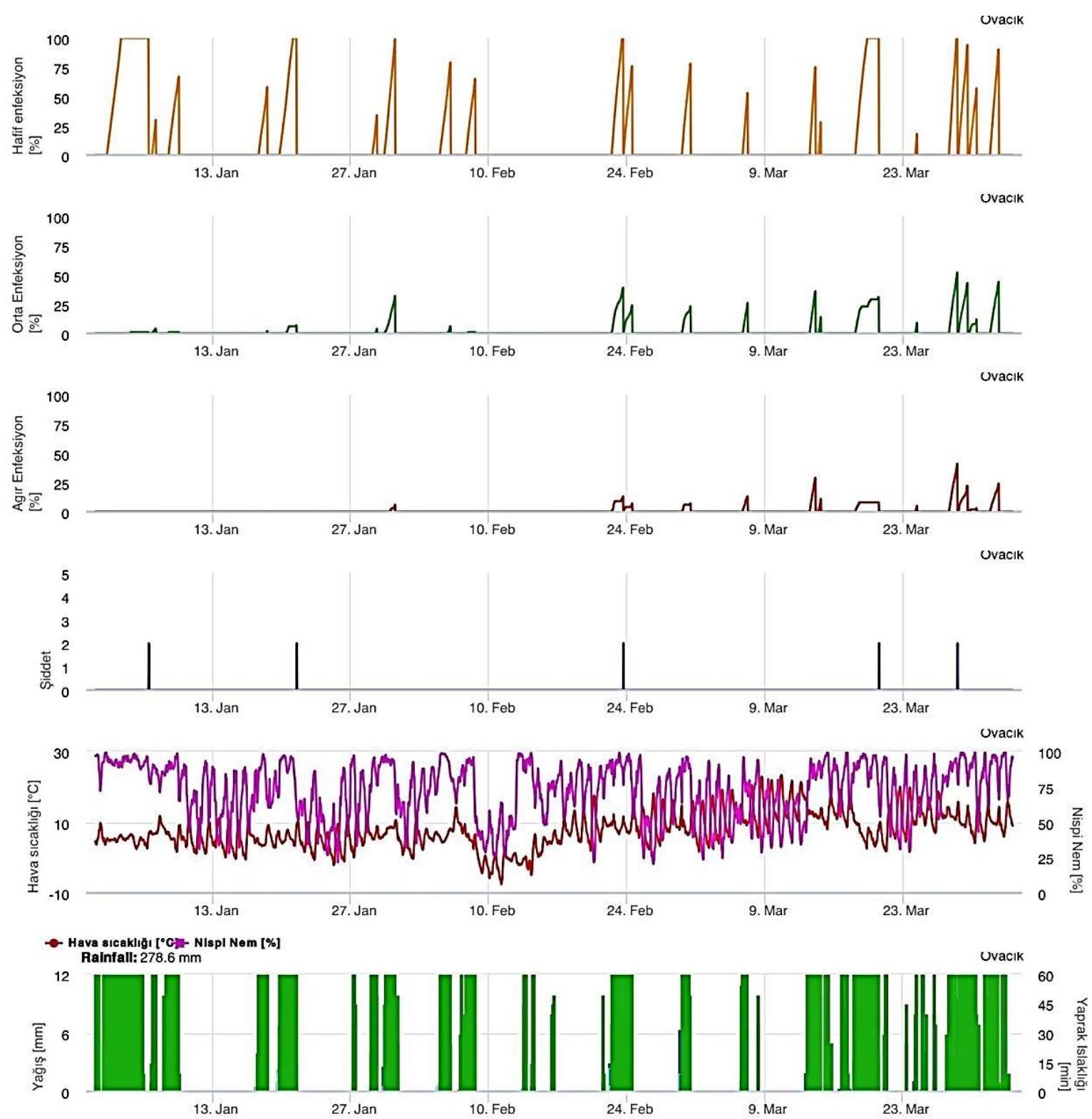

Şekil 5. Ovacık Köyü tahmin ve erken uyarı istasyonu verileri

Figure 5. Ovacık village station forecast and early warning data

Taşkuyu Köyü SYL hastalık çıkışı ve hastalık şiddetinin değerlendirilmesi

Tarımsal tahmin ve erken uyarı istasyonundan alınan veriler ve tarla kontrolleri sonucunda ilk hafif enfeksiyon oranı \%22 değerini veren iklim parametreleri $\mathrm{T}$ : $4.92^{\circ} \mathrm{C}$; RH: \%93.78; R: $5.6 \mathrm{~mm}$ ve
LWT: 60 dakika olarak ölçülmüştür. Hastalık şiddetinin 2 olarak değerlendirildiği hafif enfeksiyon oranının \%100 olduğu hava koşulları ise $\mathrm{T}: 11.76^{\circ} \mathrm{C}$; $\mathrm{RH}: \% 64.33$; R: $0 \mathrm{~mm}$ ve LWT: 20 dakika olarak bulunmuştur( Şekil 6). 

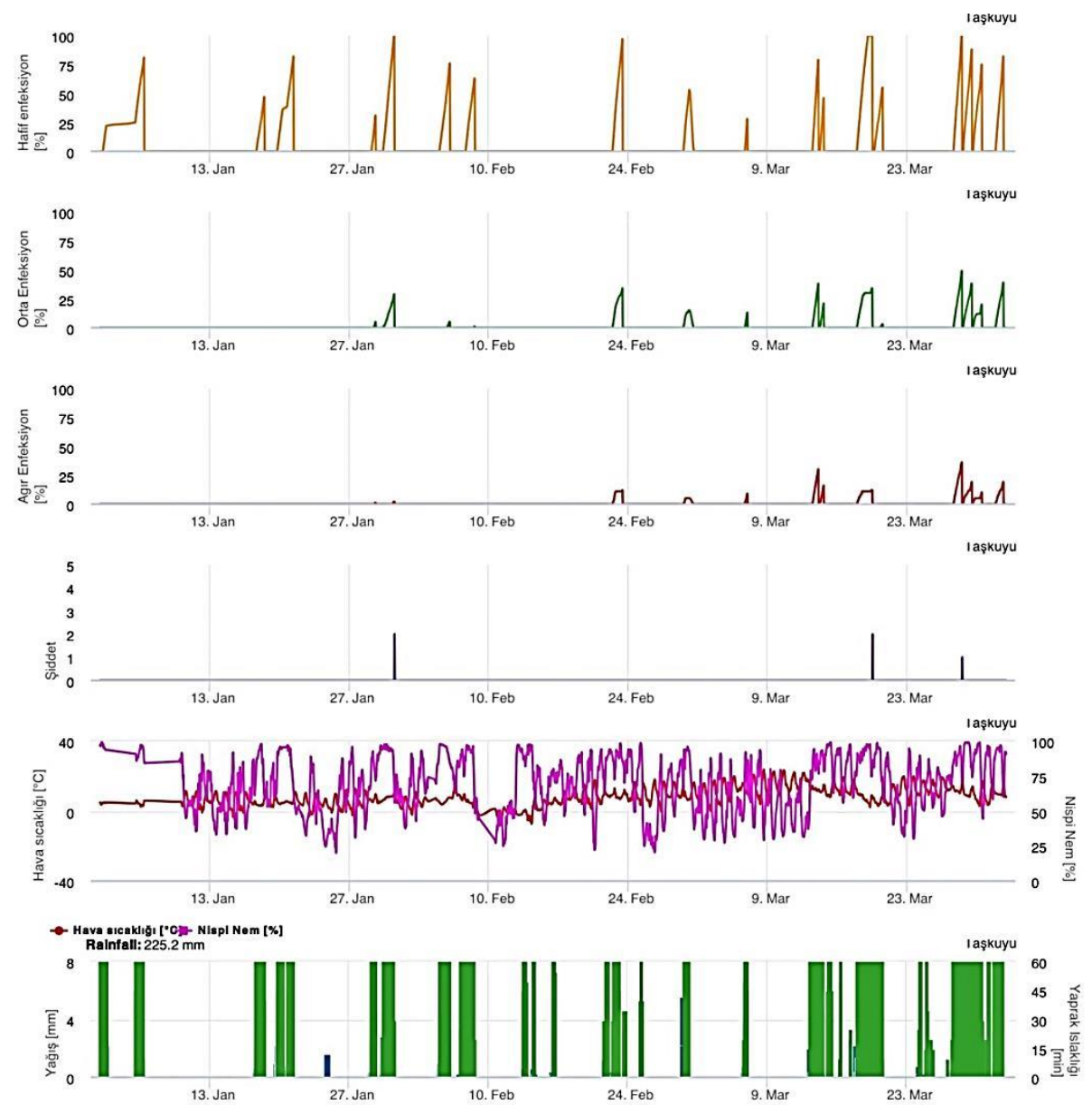

Şekil 6. Taşkuyu Köyü tahmin ve erken uyarı istasyonu verileri

Figure 6. Taşkuyu village station forecast and early warning data

Guo ve ark. (2008) Z.tritici konidilerinin çimlenebilmesi için minimum $2-3^{\circ} \mathrm{C}$, maksimum $33-37^{\circ} \mathrm{C}$ ve optimum sıcaklığın ise $20-25^{\circ} \mathrm{C}$ olması gerektiğini rapor etmişlerdir. Ayrıca sıcaklığın $2^{\circ} \mathrm{C}$ altına düşmesi durumunda patojenin enfeksiyon kabiliyetini kaybedeceğini belirtmişlerdir. Düşük sıcaklık derecelerinin $\left(4^{\circ} \mathrm{C}\right)$ spor çimlenmesi, miselyal gelişim ve piknit oluşumu için gereken süreyi uzatabileceğini rapor etmişlerdir. Coakley ve Shaner (1987) de sıcaklığın (11-, 18-, 25C) artmasıyla birlikte yüksek nemli periyotların, penetrasyon ve miselyal gelişim için gerekli olduğunu ifade etmişlerdir. Ayrıca hastalık belirtisinin ilk görüldüğü en düşük sıcaklık değerinin $5^{\circ} \mathrm{C}$ olduğu, $2-3^{\circ} \mathrm{C}$ deki sıcaklıklarda ise hastalık belirtilerine rastlanılmadığı tespit edilmiştir.

Buğday SYL hastalığına ait 4 izolat ve farklı sıcaklık değerleri (4-, 15-, 25-, 30-, 35 C) kullanılarak yapılan çalışmada, farklı sıcaklık değerlerine maruz bırakılan fungus izolatları sıcaklık değişimlerinden etkilenmiştir( $P \leq 0.05)$. Sıcaklık optimum değerlerden uzaklaştıkça patojenin birim alandaki spor yoğunluğu, ortalama büyüme çapı ve birim hacimdeki spor sayısında azalma olmuştur(Kılınç, 2018).

Djurleve ark. (1996) Septoria nodorum'un buğday yaprakları üzerindeki etkinliğinin yaprak ıslaklık süresine, yağış ve orantılı neme bağlı olduğunu ve buna rüzgar eklendiğinde yaprak ıslaklık süresinin artacağını, bununda enfeksiyonu neredeyse yarı yarıya arttırabileceğini rapor etmişlerdir. Aynı çalışmada yaprak ıslaklık süresinin 60 dakika üzerinde olduğu orantılı nemin \%90'ı geçtiği durumlarda hastalık şiddetinin arttığı gözlemlenmiştir.

Birçok ülkede denetimli kontrol için tahmin modelleri oluşturmak ve veri alışverişini dijital hale getirmek için çalışmalar yapılmaktadır. Çoğu model çok hızlı değişkenlik gösteren hastalıklar veya düzenli olarak kontrol edilmesi gereken hastalıklar için geliştirilmiştir. Oluşturulan tahmin modelleri ile hastalıklar ve zararlıların düşük maliyet ve minimum kimyasal uygulama ile kontrol edilmesi sağlanabilir. Nem, sıcaklık ve yaprak ıslaklık süresine göre ayarlanmış ilaçlama 
peryodu ve süreleri, coğrafi bilgi sistemi ile koordine edilerek hassas tarım yönetimine katkı sağlayabilir (Bouma, 2007).Örneğin Leptosphaeria nodorum ve Mycosphaerella graminicola'nın enfeksiyon yapması günde $1 \mathrm{~mm}$ 'den fazla yă̆ış ve çeşitlerin duyarlıığına bağlıdır. Bu patojene karşı alınan kültürel önlemler ve kullanılan fungisitlerin etkinliği, buğday bitkisi çeşidi, SYL ırkı ve çevre faktörleri arasındaki ilişkilerin anlaşılması ve buna göre kontrol mekanizmalarının oluşturulması büyük önem arz etmektedir (Hardwick ve ark., 2001 ). Lovell ve ark. (2004) SYL hastalığının buğday bitkisinde yayılmasının bitki üzerine sıçrayan yağışların yoğun olmasına bağlı olduğu bildirilmiş, yaprak ıslaklık süresinin enfeksiyon üzerinde belirleyici rol oynadığını ifade etmişlerdir.

\section{Sonuçlar}

$\mathrm{Bu}$ çalışmada tarımsal erken uyarı istasyonlarından alınan veriler ışığında patojenin enfeksiyon zamanı üzerinde sıcaklık, nem, yağış ve yaprak ıslaklık süresinin etkili olduğu gözlemlenmiştir. İlk hastalık belirtilerinin ortaya çıkışında yüksek nem ( $\geq \% 90$ ) ve $1 \mathrm{~mm}$ üzerindeki yağış miktarının etkili olduğu görülmüş, bununla beraber yağışın durması $(R=0 \mathrm{~mm})$ ve sıcaklık artışının $\left(\geq 8^{\circ} \mathrm{C}\right)$ olduğu durumda hastalık şiddetinin 2 olarak değerlendirilmesine neden olmuştur. Kılınç, (2018) sıcaklık artışının etmen üzerindeki etkisi ile ilgili yapmış oldukları çalışmada, yüksek sıcaklıkta $\left(30^{\circ} \mathrm{C}\right.$ ve $\left.35^{\circ} \mathrm{C}\right)$ patojene ait protein miktarı azalmış, prolin, proteaz, melanin ve malonadialdehit (MDA) değerlerinde ise artış olmuştur $(P \leq 0.05)$. Buna bağlı olarak fungusun izolatları arasında gelişme farklılıkları oluştuğu saptanmıştır. Patojenin CU100StA4 nolu izolatının birim alandaki spor yoğunluğu, ortalama büyüme çapı, birim hacimdeki spor sayısı ve ürettiği proteaz miktarı diğer izolatlardan yüksek çıkmıştır. Patojenin CU107StH110 nolu izolatının prolin, melanin ve malonadialdehit değerleri, diğer izolatlardan daha yüksek çıkmıştır. Fungusun farklı sıcaklıklarda proteaz enzim üretimi ile misel uzunluğu, protein ve prolin değerleri arasında pozitif bir ilişki olduğu şeklinde rapor etmiştir

Hastalık belirtilerinin ortaya çıkışı üzerinde iklim faktörlerinin yanı sıra buğday çeşidi, ekim normu, ekim zamanı, ekim yapılan alanın konumu gibi faktörlerinde bölgede çıkış zamanı üzerinde etkili olduğu tespit edilmiştir. Adıyaman illi Samsat Illçesinde yapılan bu çalışma ile ilk hastalık belirtilerinin 2020 yılı için ocak ayının ilk haftasında ortaya çıktığı belirlenmiş, kurulan istasyonların $10 \mathrm{~km}$ çapında bir alandan bilgi aldığı ve istasyonun verilerinin ilçenin tamamını temsil ettiği görülmüştür. Samsat illçesinin geçmiş yıllardaki meteorolojik verileri Adıyaman ili iklim verileri ile paralellik taşıdığından elde edilen bulgular il genelindeki buğday alanlarında hastalığa neden olan patojen için önemli bir veri kaynağı olmuştur. Dolayısı ile gelecek yıllardaki muhtemel hastalık çıkışı ve hastalığın potansiyel ilerlemesi hakkında tahmin verileri elde edilmiştir. $\mathrm{Bu}$ istasyonların ve verilerin diğer bölgesel hastalıklar için de geliştirilmesi küresel iklim değişikliğin altında bulunan bölgeler için önemli bir veri kaynağı sağlayacaktır. Özellikle epidemi hatta pandemi yapma potansiyeline sahip hastalık etmenleri için uygun iklim koşullarının önceden belirlenmesinin ürün kayıplarını azaltarak ülke ekonomisine katkı sağlayacağı öngörülmüştür.

Erken uyarı ve tahmin sisteminin, yapay zekâ desteği ile oluşturulan algoritma ile geliştirilmesi gelecekte büyük bir yer tutacak dijital bitki patolojisi çalışmalarına da büyük destek sağlayacak potansiyele sahiptir.

Çıkar çatışması: "Makale yazarları, aralarında herhangi bir çıkar çatışması olmadığını beyan eder".

Yazar Katkısı: Nevzat KILINÇ, çalışmayı tasarlayarak denemeyi kurmuştur, Nevzat KILINÇ ve Ela TOHUMCU çalışmayı yürütmüş, Murat DiKiLiTAŞ verileri analiz etmiştir.

\section{Kaynaklar}

Akan, K., Çetin, L., Albostan, S., Düşünceli, F. ve Mert, Z., (2006). İç Anadolu'da görülen önemli tahıl ve nohut 
hastalıkları. Tarla Bitkileri Merkez Araştırma Enstitüsü Dergisi, 15 (1-2), 29-48.

Aktaş, H., (2001). Önemli hububat hastalıkları ve survey yöntemleri. Tagem, Ankara, $80 \mathrm{~s}$.

Beest, D.E., Paveley, N.D., Shaw, M.W. ve Bosch, F., (2008). Disease weather relationships for powdery mildew and yellow rust on winter wheat. Phytopathology, 98, 609-617.

Bremer, H., Ismen, H., Karel, G., Ozkan, H. ve Özkan, M., (1948). Contributions to the knowledge of the parasitic fungi of Turkey Part II. Journal Article Rev. Fac. Sci. Univ., 13(1):1-53.

Coakley, S.M., Mcdaniel, L.R. ve Shaner, G., (1985). Model for predicting severity of septoria tritici blotch on winter wheat. Phytopathology, 75: 1245-1251.

Dikilitaş, M., Çelik Oğuz, A. ve Karakaya, A., (2018). Extracellular protease activity and glucose production in Isolates of net blotch pathogens differing in virulence. Zemdirbyste-Agriculture, 105(1): 89-94.

Djurle, A., Ekbom, B. ve Yuen, J.E., (1996). The relationship of leaf wetness duration and disease progress of glume blotch, caused by stagonospora nodorum, in winter wheat to standard weather data. European Journal Of Plant Pathology, 102, 9-20.

Bouma, E., (2007). Computer aids for plant protection, historical perspective and future developments. EPPO Bulletin, 37, 2, (247-254).

FAO, (2018). Food And Agriculture Organization Of The United Nations http://Www.Fao.Org/Faostat/En/\#Data/Qc.

Fones, H., Gurr, S., (2015). The impact of septoria tritici blotch disease on wheat: an eu perspective. Fungal Genet. Biol. 79:3-7.

Gladders, P., Paveley, N.D., Barrie, I.A., Hardwick, N.V., Hims, M.J., Langton, S. ve Taylor, M.C., (2001). Agronomic and meteorological factors affecting the severity of leaf blotch caused by mycosphaerella graminicola in commercial wheat crops in England. Annals Of Applied Biology, 138, 301-311.

Guo, J.R. ve Verreet, J.A., (2008). Formation and germination of septoria tritici secondary conidia as affected by environmental factors. Journal of Phyto pathology,156: 635-637.

Henze, M., (2008). Developing a growing parameter -and weather-dependent infestation forecast of Septoria tritici Cuviller Verlag, Göttingen.

İren, S., (1962). Tarla bitkileri hastalıkları. Ayyıldız Matbaası, Ankara, 3-94s.

Ilgen, M. Z., Karakaya, A., Çelik Oğuz, A. (2017). Leaf diseases occurring on barley and wheat fields in Çubuk district of Ankara, Turkey. Works of the
Faculty of Agriculture and Food Sciences University of Sarajevo. Vol. XLII, 67/2: 210-215.

Kılınç, N., (2018). Buğday leke hastalığı [Zymoseptoria Tritici (Desm. Quaedvlieg \& Crous)] patojeninin farklı izolatlarının biyokimyasal özelliklerinin belirlenmesi. Https://Tez.Yok.Gov.Tr/Ulusaltezmerkezi/Tez No : 528635.

Kurt, Ş., Tok, F.M., (2006). Influence of Inokulum concentration, leaf age, temperature and duration on leaf wetnes on septoria blight of parsley. Crop Protection, 25: 556-561.

Kurt, Ş. (2016). Bitki fungal hastalıkları. Akademisyen Kitap Evi, İstanbul, $214 \mathrm{~s}$.

Lovell, D.J., Hunter, T., Powers, S.J., Parker, S.R., ve Van Den Bosch, F., (2004a). Effect of temperature on latent period of septoria leaf blotch on winter wheat under outdoor conditions. Plant Pathology, 53, 170-181.

Lovell, D.J., Parker, S.R., Hunter, T., Welham, S.J. ve NiCHOLS, A.R., (2004b). Position of inoculum in the canopy affects the risk of septoria tritici blotch epidemics in winter wheat. Plant Pathology, 53, 1121.

Lovell, D. J., Parker, S. R., Paveley, N. D. ve Worland, A. J., (2002). Understanding field resistance mechanisms for improved control of septoria tritici. Plant Protection Science, 38, 165-169.

Özdemir, H. Y., Karakaya, A., Çelik Oğuz, A. (2017). Kırıkkale ilinde buğday ve arpa ekim alanlarında görülen fungal yaprak hastalıklarının belirlenmesi. Bitki Koruma Bülteni 57 (2): 89-112.

Parker, S. R., Welham, S., Paveley, N. D., Foulkes, J. ve SCOTT, R. K., (2004). Tolerance of septoria leaf blotch In winter wheat. Plant Pathology, 53, 1-10.

Shaw, M. W., Bearchell, S. J., Fitt, B. D. L. ve Fraaije, B. A., (2008). Long-term relationships between enviromentand abundance in wheat of phaeosphaeria nodorum and mycosphaerella graminicola. New Phytologist, 177, 229-238.

Sidhu, Y.S., Chaudhari, Y.K., Usher, J., Cairns, T.C., Csukai, M. ve Haynes, K., (2015). A suite of gateway compatible ternary expression vectors for functional analysis in zymoseptoria tritici. Fungal Genet. Biol., 79:180-185.

Thomas, M., Chaloner, H. N., Fones, V. V., Daniel, P., Bebberand S. J. ve GURR, A., (2019). New mechanistic model of weather-dependent septoria tritici blotch disease risk. Phil. Trans. R. Soc., B 374 20180266.

Torriani, S.F.F., Brunner, P.C., Mcdonald, B.A. ve Sierotzki, H., (2009). Qol resistance emerged in dependently at least 4 times in European populations of mycosphaerella graminicola. Pest Manage. Sci., 65:155-162. 